Article

\title{
Partial Purification and Characterization of a Thermostable ß-Mannanase from Aspergillus foetidus
}

\section{Juliana da Conceição Infante de Marco ${ }^{1}$, Geraldo Pereira de Souza Neto ${ }^{2}$, Carlos Frederico de Souza Castro ${ }^{2}$, Michele Michelin ${ }^{3}$, Maria de Lourdes T. M. Polizeli ${ }^{3}$ and Edivaldo Ximenes Ferreira Filho ${ }^{1, *}$}

1 Laboratory of Enzymology, Cellular Biology Department, University of Brasília, Brasília 70910-900, Brazil; E-Mail: ju.infante@gmail.com (J.C.I.M.)

2 Federal Institute of Education, Science and Technology of Goiás, Rio Verde, Goiás 75901-970, Brazil; E-Mails: quimica.geraldo@gmail.com (G.P.S.N.); carlosfscastro@gmail.com (C.F.S.C.)

3 Department of Biology, Faculty of Philosophy, Sciences and Letters of Ribeirão Preto, University of São Paulo, Ribeirão Preto, São Paulo 14040-901, Brazil; E-Mails: mimichelin.bio@gmail.com (M.M.); polizeli@ffclrp.usp.br (M.L.T.M.P.)

* Author to whom correspondence should be addressed; E-Mail: eximenes@unb.br; Tel.: +55-61-3107-2976; Fax: +55-61-3107-2904.

Academic Editors: Helmut Martin Hügel and Takayoshi Kobayashi Received: 23 July 2015 / Accepted: 15 October 2015 / Published: 20 October 2015

\begin{abstract}
An extracellular $\beta$-mannanase was isolated from samples of crude extract of the mesophilic fungus Aspergillus foetidus grown on soybean husk as a carbon source. The induction profile showed that $\beta$-mannanase reached a maximum activity level $(2.0 \mathrm{IU} / \mathrm{mL})$ on the 15 th day of cultivation. The enzyme was partially purified by ultrafiltration and gel filtration chromatography procedures and was named Man 58. Sodium dodecyl sulfate-polyacrilamide electrophoresis and zymogram analysis of Man 58 showed two bands of approximately 43 and $45 \mathrm{kDa}$ with $\beta$-mannanase activity. Ultrafiltration showed that $\beta$-mannanase activity was only detected in the concentrated sample. Man 58 was most active at $60{ }^{\circ} \mathrm{C}$ and at $\mathrm{pH} 4.0$. It was thermostable in the temperature range of $40-60{ }^{\circ} \mathrm{C}$ for eleven days, and the half-life at $70{ }^{\circ} \mathrm{C}$ was ten days. Man 58 showed $K_{\mathrm{m}}$ and $V_{\max }$ values of $3.29 \mathrm{mg} / \mathrm{mL}$ and $1.76 \mathrm{IU} / \mathrm{mL}$ respectively, with locust bean gum as a substrate. It was mostly activated by $\mathrm{FeSO}_{4}$ and $\mathrm{CoCl}_{2}$ and inhibited by $\mathrm{MgSO}_{4}, \mathrm{FeCl}_{3}, \mathrm{CuSO}_{4}, \mathrm{MgCl}_{2}, \mathrm{ZnCl}_{2}, \mathrm{ZnSO}_{4}, \mathrm{CaCl}_{2}, \mathrm{CuCl}_{2}, \mathrm{KCl}$ and ethylenediaminetetraacetic acid (EDTA). Phenolic compounds did not inhibit the
\end{abstract}


enzyme. On the other hand, auto-hydrolysis liquor showed an inhibitory effect on Man 58 activity.

Keywords: soybean husk; $\beta$-mannanase; Aspergillus foetidus

\section{Introduction}

Hemicelluloses are a complex group of polysaccharides found in plant cell walls in close association with lignin and cellulose. Mannan, one of the major constituent groups of hemicellulose in softwood, is composed of linear or branched polymers derived from sugars such as D-mannose, D-galactose, and D-glucose [1-3]. The linear mannan structure is composed of linear main chains of 1,4-linked $\beta$-D-mannopyranosyl residues [4]. It also contains galactoglucomannan with mannose/glucose/galactose residues in a ratio of 3:1:1 and glucomannan with mannose/glucose residues in the ratio of 3:1 [5]. The mannan structure may be substituted with branches containing acetyl and galactosyl residues. The enzyme systems that catalyze hydrolysis of mannan include $\beta$-mannanase, $\beta$-glucosidase, and $\beta$-mannosidase. Additional enzymes such as acetyl mannan esterase and $\alpha$-galactosidase are important for the removal of side chain groups of mannan [6]. Based on the primary structures of their catalytic domains, $\beta$-mannanases are found in the glycoside hydrolase families 5, 26, and $113[4,7,8]$. These enzyme families present a double-displacement mechanism with retention of anomeric configuration. $\beta$-mannanases can be produced by microorganisms, such as bacteria and filamentous fungi [9]. According to Zhang and Sang [10], the filamentous fungi strains are the most interesting producers by right of higher yields of extracellular enzymes and association with cellulases production. Thermostable $\beta$-mannanases have great advantages, such as reducing the risk of contamination, increasing the substrate solubility, and improving the mass transfer rate $[8,10]$.

Mannan-degrading enzymes are not only of interest in plant physiology, but also have potential applications in a wide range of industrial enzyme markets such as in the food and feed industries [3]. $\beta$-Mannanases can be applied to preparation of mannooligosaccharides improving digestion and absorption of nutrition in feedstuff, reducing viscosity of the coffee extracts and extraction of vegetable oils from leguminous seeds [10,11]. As example of $\beta$-mannanase application, Lee et al. [12] reported that the supplementation of $\beta$-mannanase in feeds containing guar meal reduced intestinal viscosity and feed conversion ratio, increased body weight and alleviated the deleterious effects associated with guar meal feeding. Agro-industrial residues, including soybean husk, represent an alternative source available for microbial growth and enzyme production [13]. The residual plant biomass is a valuable source of lignocellulose components, which can be converted into various value-added products [14]. The treatment of spent coffee ground (a residue generated in the production of instant coffee) with endo-mannanase is reported as an alternative for the release of mannooligosaccharides, which have potential application as prebiotic products in human and animal feed [11]. Zhang et al. [10] reported an enzyme solution from Penicillium chrysogenum QML-2 (containing xylanase and mannanase activities) that was applied to saccharification of aqueous ammonia solution pretreated corn cob powder. In this case, maximum yields of xylose $(236.63 \mathrm{mg} / \mathrm{g})$ and reducing sugar $(553.94 \mathrm{mg} / \mathrm{g})$ were obtained. 
The focus of the present work was to characterize the properties of a $\beta$-mannanase preparation (Man 58) from Aspergillus foetidus (A. foetidus) when grown on soybean husk as substrate. To our knowledge, this is the very first report describing partial purification and characterization of a $\beta$-mannanase from $A$. foetidus.

\section{Experimental Section}

\subsection{Chemicals}

All substrates were purchased from Sigma Chemical Co. (St. Louis, MO, USA), unless indicated otherwise. Soybean husk was kindly provided by a local supplier. Sephacryl S-100 was from GE Healthcare Life Sciences (São Paulo, Brazil). All experiments were carried out with five replicates. The acceptable standard deviation was less than $20 \%$ of the mean.

\subsection{Residue Pretreatment}

Soybean husk was thoroughly washed with tap water and autoclaved at $121^{\circ} \mathrm{C}$ for $2 \mathrm{~h}$. After autoclaving, it was dried at $60{ }^{\circ} \mathrm{C}$ for $48 \mathrm{~h}$ and ground to form a relatively homogeneous blend. A fine powder was obtained and used as the carbon source.

\subsection{Bromatological Analysis}

For bromatological analysis of soybean husk, lignocellulose content, including lignin, hemicellulose and cellulose, was determined as described elsewhere [15].

\subsection{Organism and Enzyme Production}

A. foetidus was obtained from the fungus culture collection of the Enzymology Laboratory, University of Brasília, Brazil (authorization to access and ship sample component of genetic heritage number 010237/2015-1). It was isolated from an area of native cerrado (Brazilian savannah) in the Federal District of Brazil and maintained on PDA medium (2\% potato broth, $2 \%$ dextrose and $2 \%$ agar). The spore concentration was determined by counting under a microscope with a Neubauer chamber, and was adjusted with sterile saline solution $(0.9 \%)$ to a final concentration of $10^{8}$ spores $/ \mathrm{mL}$. For $\beta$-mannanase production, an aliquot $(2.5 \mathrm{~mL})$ of spore suspension was transferred to an Erlenmeyer flask. The cultures were incubated at $28{ }^{\circ} \mathrm{C}$ with constant agitation at $120 \mathrm{rpm}$ for 20 days in a liquid medium containing $(w / v): 0.7 \% \mathrm{KH}_{2} \mathrm{PO}_{4}, 0.2 \% \mathrm{~K}_{2} \mathrm{HPO}_{4}, 0.05 \% \mathrm{MgSO}_{4} \cdot 7 \mathrm{H}_{2} \mathrm{O}$ and $0.16 \%\left(\mathrm{NH}_{4}\right)_{2} \mathrm{SO}_{4}$ at $\mathrm{pH} 7.0$, with $1 \%(w / v)$ soybean husk as the carbon source. After fungal growth, the culture medium was previously filtered through a Büchner funnel with filter paper (Whatman No. 1), and stored at $4{ }^{\circ} \mathrm{C}$. The resulting filtrate, hereafter referred to as crude extract, was used as a source of $\beta$-mannanase. For enzyme induction, aliquots were harvested every $24 \mathrm{~h}$ for 20 days and used to estimate the $\beta$-mannanase activity and protein concentration. 


\subsection{Enzyme Assay}

$\beta$-Mannanase, endoglucanase (CMCase), xylanase and pectinase activities activity were determined by mixing $25 \mu \mathrm{L}$ of enzyme sample with $50 \mu \mathrm{L}$ of $1 \%(w / v)$ mannan (locust bean gum), carboxymethyl cellulose, oat spelt xylan and pectin from citrus fruit, respectively, at $50{ }^{\circ} \mathrm{C}$ for $30 \mathrm{~min}$. The amount of reducing sugar released was measured using dinitrosalicylic reagent [16]. The enzyme activity was expressed as micromoles of reducing sugar formed per minute per milliliter of enzyme solution (IU/mL). Protein concentration was determined by the Bradford method [17] using a Protein Assay Kit (Bio-Rad Laboratories, Hercules, CA, USA) and bovine serum albumin as the reference protein according to the manufacturer's instructions.

\subsection{Partial Purification of Man 58}

The crude extract was concentrated approximately 10 -fold at $10{ }^{\circ} \mathrm{C}$ by ultrafiltration using an Amicon membrane System (Amicon Inc., Beverly, MA, USA) with a $10 \mathrm{kDa}$ cutoff. Aliquots of the concentrated sample $(10 \mathrm{~mL})$, hereafter referred to as retentate, were fractionated by gel filtration chromatography at room temperature on a Sephacryl S-100 column $(72 \times 3.0 \mathrm{~cm})$ equilibrated with $50 \mathrm{mM}$ sodium acetate buffer, $\mathrm{pH}$ 4.0. Fractions $(4 \mathrm{~mL})$ were eluted at a flow rate of $15 \mathrm{~mL} / \mathrm{h}$, and those corresponding to $\beta$-mannanase activity were pooled and stored at $4{ }^{\circ} \mathrm{C}$ for further characterization.

\subsection{Electrophoresis and Zymogram}

Sodium dodecyl sulfate-polyacrylamide gel electrophoresis (SDS-PAGE) was carried out using a $12 \%$ gel [18]. After electrophoresis, the protein bands were silver stained according to the method of Blum et al. [19]. Replicate denaturing electrophoretic gels containing $0.1 \%$ locust bean gum were submitted to zymogram analysis [20]. The molecular masses of $\beta$-mannanase samples were estimated using low molecular mass markers from GE Healthcare Life Sciences.

\subsection{Enzyme Characterization}

The influence of temperature on $\beta$-mannanase activity was measured by performing a standard activity assay at temperatures ranging from 30 to $80{ }^{\circ} \mathrm{C}$. The temperature stability of $\beta$-mannanase was determined by pre-incubating the enzyme samples (Man 58 and retentate) at 40, 50, 60, 70 and $80{ }^{\circ} \mathrm{C}$ and removing samples at intervals to measure the activity as described before. The influence of $\mathrm{pH}$ on $\beta$-mannanase activity was assessed by incubating $25 \mu \mathrm{L}$ of enzyme sample, $50 \mu \mathrm{L}$ of mannan $(1 \% w / v)$ and $75 \mu \mathrm{L}$ of each of the following buffers: $50 \mathrm{mM}$ sodium acetate ( $\mathrm{pH} 3.0-6.0$ ), $50 \mathrm{mM}$ sodium phosphate ( $\mathrm{pH} 6.0-7.5)$ or $50 \mathrm{mM}$ Tris- $\mathrm{HCl}(\mathrm{pH} 7.5-9.0)$, at $50{ }^{\circ} \mathrm{C}$. All buffers, regardless of $\mathrm{pH}$, were adjusted to the same ionic strength with $\mathrm{NaCl}$. The effects of several salts $\left(\mathrm{MgSO}_{4}, \mathrm{FeSO}_{4}, \mathrm{CoCl}_{2}, \mathrm{FeCl}_{3}\right.$, $\mathrm{CuSO}_{4}, \mathrm{CaCl}_{2}, \mathrm{ZnCl}_{2}, \mathrm{ZnSO}_{4}, \mathrm{CuCl}_{2}, \mathrm{KCl}$ and $\mathrm{NaCl}$ ) and EDTA on $\beta$-mannanase activity were tested after $20 \mathrm{~min}$ of incubation at $28{ }^{\circ} \mathrm{C}$ in the presence of the individual reagents at final concentrations of 1.0 and $10 \mathrm{mM}$, followed by a standard $\beta$-mannanase assay under the following conditions: $25 \mu \mathrm{L}$ of Man $58,75 \mu \mathrm{L}$ of the appropriate reagent and $50 \mu \mathrm{L}$ of $\beta$-mannan. For the kinetic experiments, galactomannan was used as a substrate in a concentration range of $0.33-26.6 \mathrm{mg} / \mathrm{mL}$. The substrates were saturating and the enzyme activities were proportional to the amount of enzyme added. $K_{\mathrm{m}}$ and 
$V_{\max }$ values were estimated using the Michaelis-Menten equation with a non-linear regression data analysis program suitable for analysis of enzyme kinetics experiments [21]. The effect of phenolic compounds on Man 58 activity was measured by incubating the enzyme with ferulic acid, $\rho$-coumaric acid, vanillin, cinnamic acid, 4-hydroxybenzoic acid and tannic acid at concentrations of $1 \mathrm{mg} / \mathrm{mL}$. This concentration of phenolic compounds showed no interference in the DNS assay. The reaction mixture was $4.5 \mu \mathrm{L}$ of Man $58,0.5 \mu \mathrm{L}$ of phenolic compound and $10 \mu \mathrm{L}$ of mannan $(1 \% w / v)$. The inhibition effect was measured immediately after incubation of the enzymes with phenolic compounds. The assay conditions were as described above. Appropriate controls were used for each experiment and the acceptable standard deviation was less than $10 \%$ of the mean.

\subsection{Effect of Autohydrolysis Liquor}

The autohydrolytic process was carried out for 30 and $50 \mathrm{~min}$ as previously described by Michelin et al. [22]. Corncob particles were decomposed to soluble compounds. The resulting liquor samples were separated from the solid by vacuum filtration, and used as liquid substrate. The effect of liquor samples on Man 58 activity was measured by incubating $5 \mu \mathrm{L}$ of enzyme sample, $5 \mu \mathrm{L}$ of locust bean gum $(1 \% w / v)$ and $5 \mu \mathrm{L}$ of liquor solution. The assay conditions were as described above.

\section{Results and Discussion}

\subsection{Enzyme Production}

In this study, A. foetidus was grown in submerged liquid culture supplemented with soybean husk as the carbon source and screened for its ability to induce $\beta$-mannanase activity. The highest levels of enzymatic activities were observed for $\beta$-mannanase, pectinase and xylanase. The induction profile during growth of $A$. foetidus on soybean husk showed that $\beta$-mannanase activity increased steadily without a lag phase and reached the highest level $(1.987 \mathrm{IU} / \mathrm{mL})$ on the fifteenth and sixteenth days of culture, while xylanase and pectinase showed highest levels on the seventeenth day of culture with activities of $0.858 \mathrm{IU} / \mathrm{mL}$ and $0.798 \mathrm{IU} / \mathrm{mL}$, respectively (Figure 1). The growth profile was accompanied by several protein spikes, which peaked at the seventh and seventeenth days of cultivation (results not shown). This protein profile probably includes other mannan-degrading enzymes in addition to $\beta$-mannanase, which are simultaneously produced and may be involved in soybean husk breakdown. Filamentous fungi often produce multiple forms of mannan-degrading enzymes [3]. This multiplicity may be due to the requirements to bind and degrade substrates of varying complexity. Therefore, based on the growth curve of the fungus, we established fifteen days as optimal for fungal growth in liquid medium containing soybean husk.

The bromatological analysis showed that soybean husk was a rich source of lignocellulose. The highest representation (36.6\%) was found for lignin, followed by hemicellulose $(33.8 \%)$ and cellulose $(24.4 \%)$.

\subsection{Partial Purification of Man 58}

Man 58 was partially purified by a combination of ultrafiltration and gel filtration chromatography on Sephacryl S-100. This is the first report on the partial purification and characterization of a 
$\beta$-mannanase from $A$. foetidus. The ultrafiltration procedure showed that the $\beta$-mannanase activity was only found in the retentate fraction and displayed an activity level of $6.392 \mathrm{IU} / \mathrm{mL}$. Previous ultrafiltration experiments also indicated that the $\beta$-mannanase from Trichoderma harzianum (T. harzianum) was only found in the retentate [2]. In this present work, xylanase and pectinase activities were detected in both retentate and ultrafiltrate fractions, with activity levels of $5.577 \mathrm{IU} / \mathrm{mL}$ (xylanase) and $5.686 \mathrm{IU} / \mathrm{mL}$ (pectinase). For further purification, the retentate was subjected to gel filtration chromatography on Sephacryl S-100. The sample elution resulted in separation of two major peaks of protein. In this case, the $\beta$-mannanase activity was only found in the first protein peak (Figure 2). The yield of $\beta$-mannanase activity was low for all purification procedures with most of the loss occurring during the different steps of purification. In this case, the partial purification yield was $32 \%$. Fractions containing $\beta$-mannanase activity (53-65) were collected and submitted to SDS-PAGE and zymogram analysis (Figure 3). The profiles of these fractions showed several bands staining for $\beta$-mannanase activity, migrating at molecular masses varying from 30 to $45 \mathrm{kDa}$, suggesting multiple forms of $\beta$-mannanase (Figure 3). For example, fractions 60-65 showed at least four bands of $\beta$-mannanase activity while fraction 58 (designated as Man 58) presented two major bands of $\beta$-mannanase activity with molecular masses of approximately 43 and $45 \mathrm{kDa}$. The multiplicity of forms is commonly described for hemicellulases from fungi and bacteria as result of differential mRNA processing and posttranslational modifications [2,3]. These enzymes may be allozymes, products of different alleles of the same gene, isozymes or same molecules with different postmodifications. The substrate specificity of Man 58 preparation showed that $\beta$-mannanase was the major activity (1.2 IU/mL), followed in much lesser extent by activities of xylanase $(0.4 \mathrm{IU} / \mathrm{mL})$ and CMCase $(0.20 \mathrm{IU} / \mathrm{mL})$. On the other hand, avicelase, FPase and pectinase activities were not detected. Man I from T. harzianum exhibited no detectable activities of CMCase and xylanase [2]. A thermophilic $\beta$-mannanase preparation from Neosartorya fischeri was not active against beechwood xylan and barely $\beta$-glucan [8].

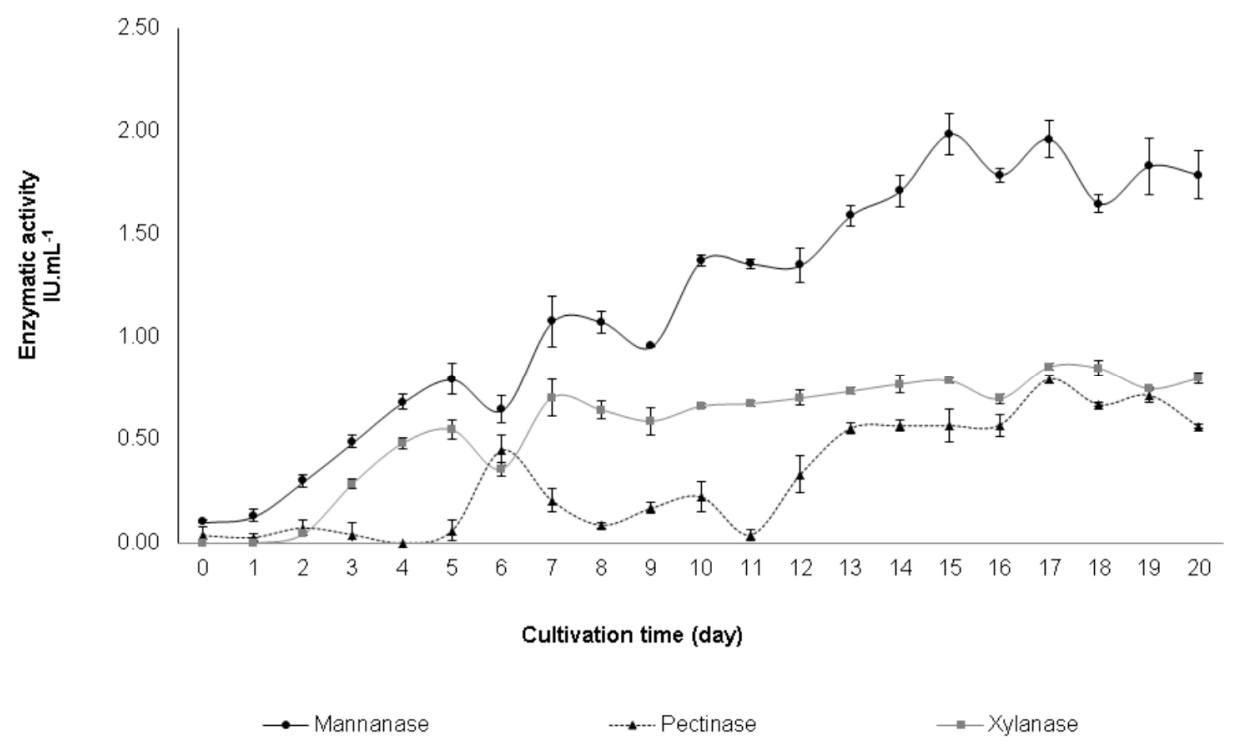

Figure 1. Induction profile of mannanase, pectinase and xylanase activities during growth of Aspergillus foetidus (A. foetidus) on soybean husk. 


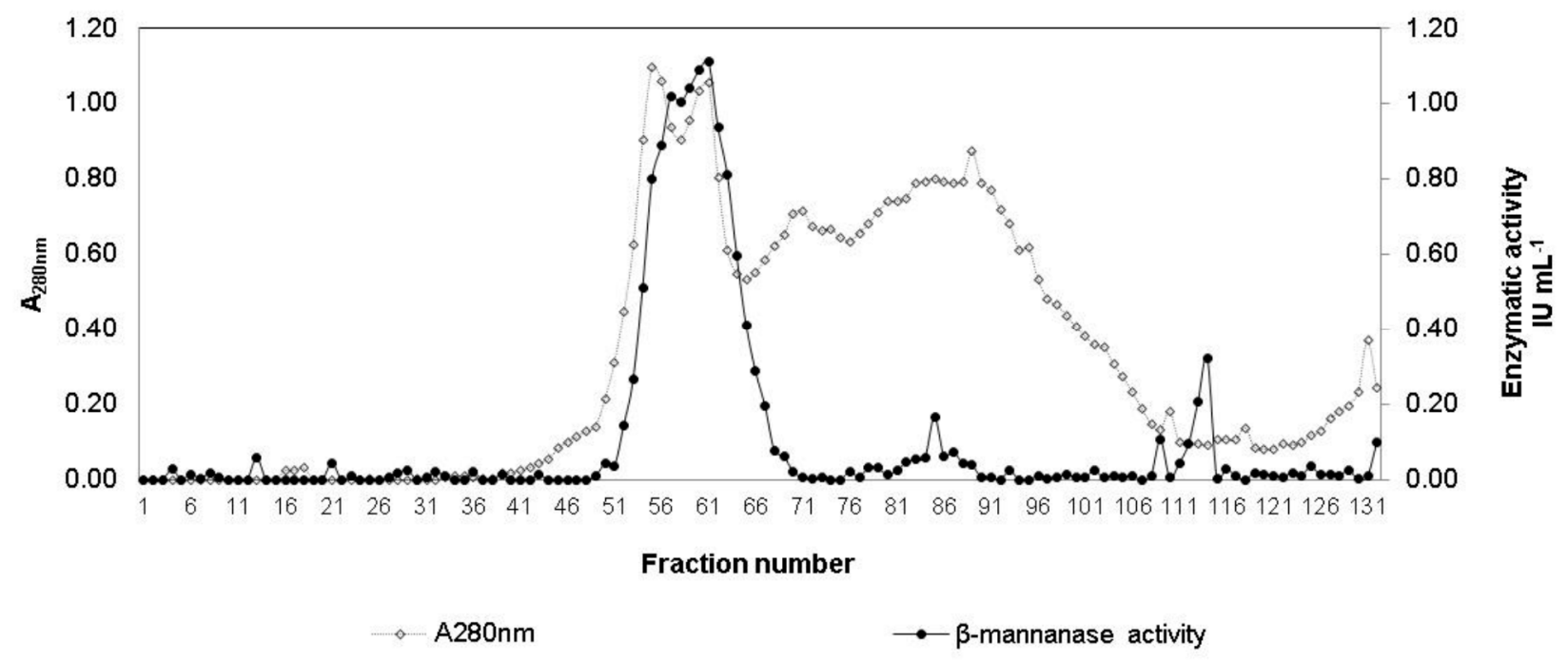

Figure 2. Elution profile of Man 58 on Sephacryl S-100 chromatography.

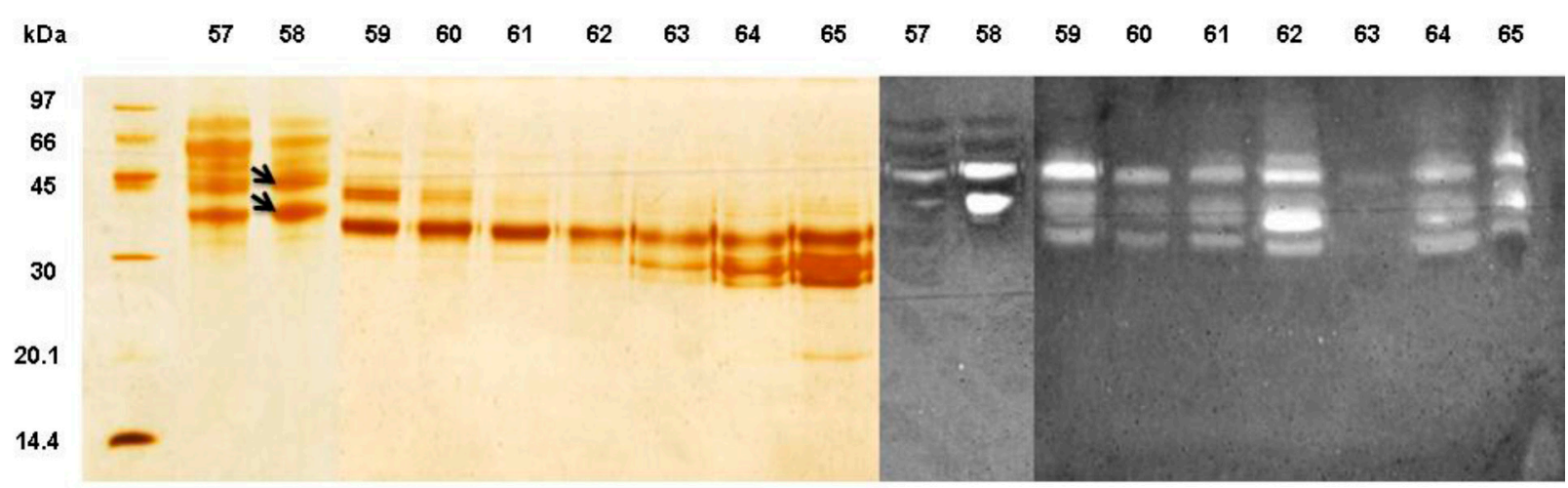

Figure 3. SDS-PAGE (12\%) of fractions collected from chromatography on Sephacryl S-100 and stained with silver nitrate (left). MW (molecular weight) marker: phosphorylase b (97 kDa), albumin (66 kDa), ovalbumin (45 kDa), carbonic anhydrase (30 kDa), trypsin inhibitor $(20.1 \mathrm{kDa})$ and $\alpha$-lactalbumin $(14.4 \mathrm{kDa})$. Zymogram of chromatography fractions (right); the arrows (left) indicate protein bands corresponding to $\beta$-mannanase activity (right) at fraction 58.

At least three $\beta$-mannanase activities were detected in the crude extract of $T$. harzianum [2]. Because of the complexity of mannan structure, the presence of $\beta$-mannanases with different specificities is required for a complete hydrolysis of $\beta$-mannan, suggesting that a synergistic action of mannan-degrading enzymes of different GH families is required for the degradation of mannan structure [4].

\subsection{Enzyme Characterization}

The effect of temperature on $\beta$-mannanase activity was evaluated using retentate and Man 58 samples. For both enzyme samples, $\beta$-mannanase was more active at $60^{\circ} \mathrm{C}$ with activities of 5.84 and $1.08 \mathrm{IU} / \mathrm{mL}$, respectively. A slow decrease in Man 58 activity was observed at higher temperatures, retaining 96\%, $91 \%$ and $85 \%$ of activity at 65,70 and $80{ }^{\circ} \mathrm{C}$, respectively (Figure 4). The pH profile of Man 58 and retentate showed that the enzyme activity remained significant in the acidic and alkaline ranges. 
$\beta$-Mannanase activity was seen over a broad $\mathrm{pH}$ range (3.0-9.0), with an optimum at $\mathrm{pH}$ 4.0. Moreover, $85 \%$ and $57 \%$ of maximum activity were retained at $\mathrm{pH} 3.5$ and 8.0, respectively. Even at $\mathrm{pH} 8.5$ and 9.0 Man 58 showed retention of 38 and $30 \%$ of activity, respectively. $\beta$-Mannanase from Aspergillus niger (A. niger) was stable at $\mathrm{pH}$ range of $3-8$ and $55^{\circ} \mathrm{C}[23]$. Thus, the ability of Man 58 to function at high temperature $\left(60\right.$ and $\left.70{ }^{\circ} \mathrm{C}\right)$ and under acidic and alkaline conditions suggests the potential application of this enzyme in pulp bleaching, which requires a thermostable and alkali-tolerant $\beta$-mannanase to cleave the mannan portion in pulps without affecting cellulose structure [24]. The $\beta$-mannanase activity from retentate was also more active at $\mathrm{pH} 4.0$. The $\beta$-mannanase from $A$. niger was less stable than Man 58, exhibiting optimum activity at $\mathrm{pH} 5.5$ and $55^{\circ} \mathrm{C}$.

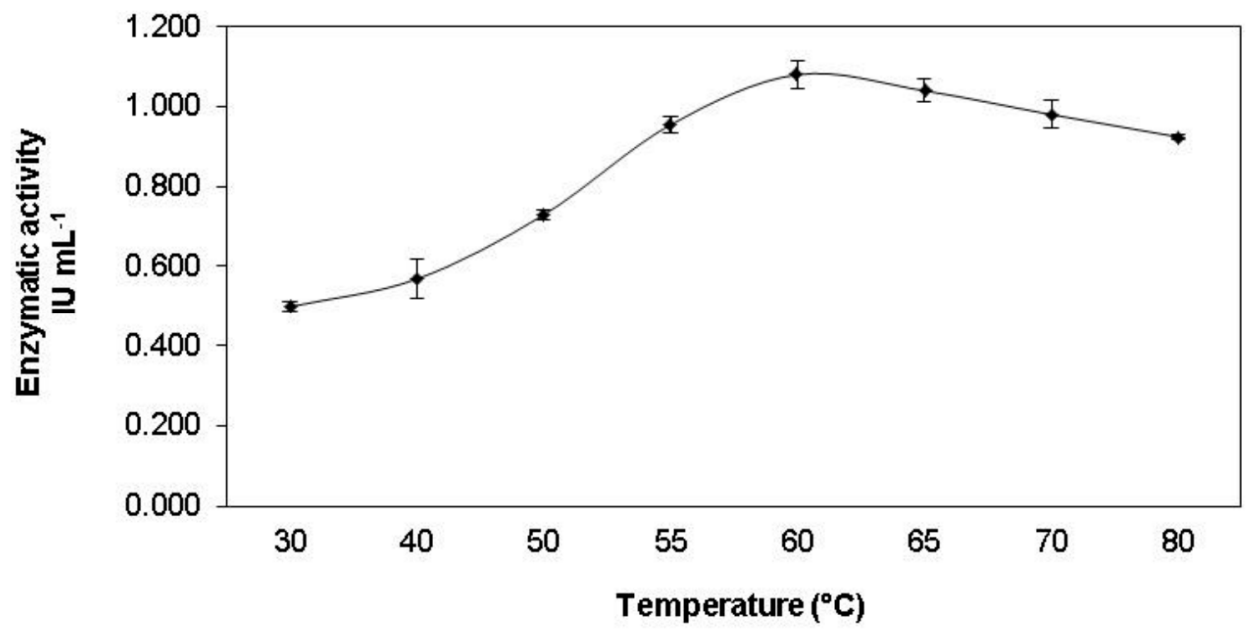

Figure 4. Effect of temperature on Man 58 activity.

An important characteristic of Man 58 and retentate was the high thermostability observed (Figure 5). Under storage conditions at 40 and $50{ }^{\circ} \mathrm{C}$, no loss of $\beta$-mannanase activity was detected after up to eleven days of incubation. It should be noted that both enzymatic samples were stable at $60{ }^{\circ} \mathrm{C}$ for at least 11 days and presented a half-life of 12 days. These data show this enzyme to be far more thermostable than $\beta$-mannanase from $A$. flavus, which presented a half-life of $6 \mathrm{~h}$ at $60{ }^{\circ} \mathrm{C}$ [25], $\beta$-mannanase from $A$. niger, which retained $50 \%$ activity after $6 \mathrm{~h}$ at $55{ }^{\circ} \mathrm{C}$ or $\beta$-mannanase from the bacterium Pantoea agglomerans A021, which was unstable at $60{ }^{\circ} \mathrm{C}$ [24]. Furthermore, Man 58 and retentate showed a half-life of $10 \mathrm{~h}$ at $70{ }^{\circ} \mathrm{C}$. In contrast, both enzyme samples were not stable at $80{ }^{\circ} \mathrm{C}$ with decline of more than $80 \%$ of their activities after $1 \mathrm{~h}$ of incubation (results not shown). The properties of Man 58 may be advantageous in biotechnological applications, including in the feed and food industries. Thermostable enzymes are capable of maintaining their activities at high temperatures (usually higher than $45{ }^{\circ} \mathrm{C}$ ), which favors the reduction in viscosity and solubility of the substrates and products by increasing the rate of reaction. Another important feature is their high resistance to the action of proteases. Additionally, biotechnological processes at elevated temperatures carry a lower risk of microbial contamination. 


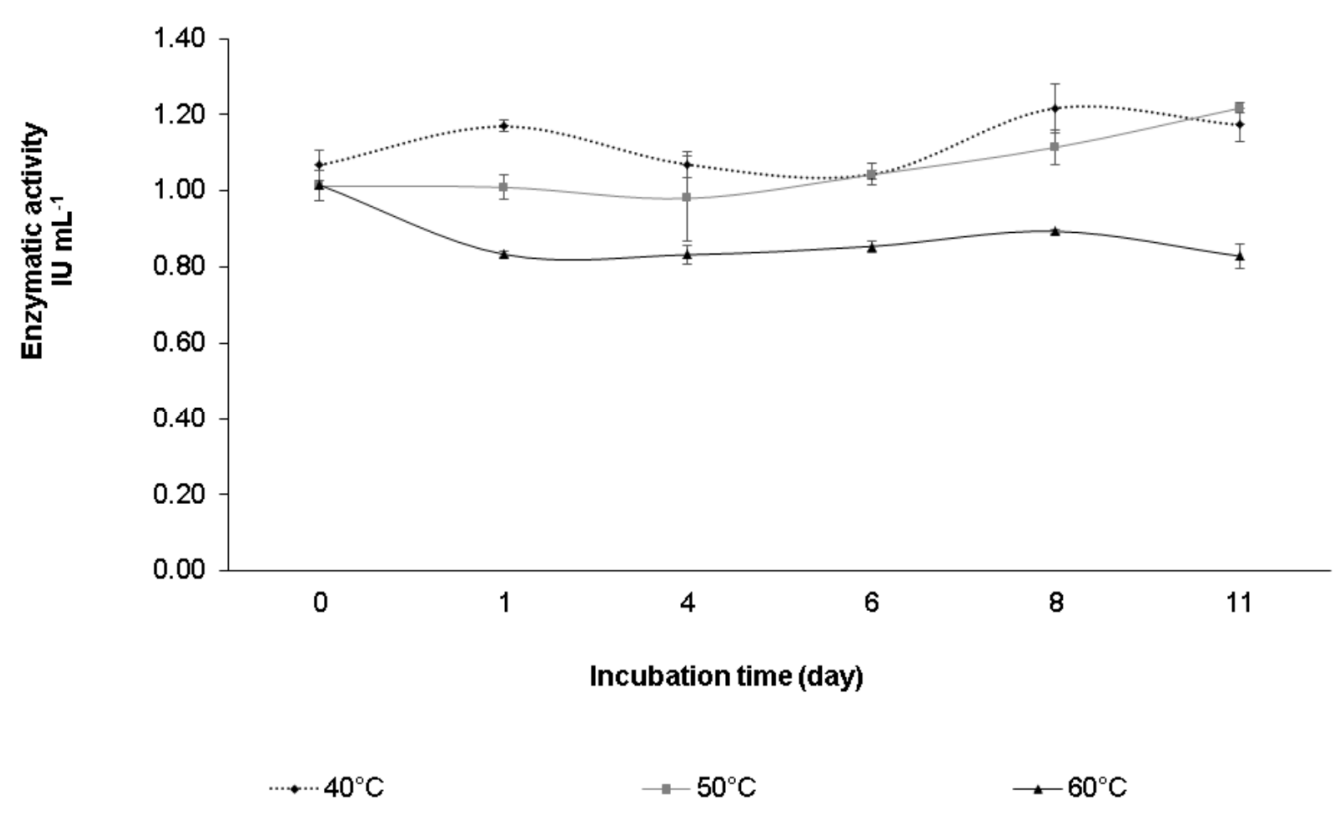

Figure 5. Thermostability profile of Man 58 at 40,50 and $60{ }^{\circ} \mathrm{C}$.

$\beta$-Mannan breakdown is dependent on several factors, including enzyme synergy, interaction with different sub-sites on the heterogeneous substrate, interaction of the subunits within the mannan-degrading enzyme system and the probable presence of binding molecules in addition to the catalytic modules [4]. Despite the difficulties in determining kinetic parameters with a polymeric and rather undefined substrate (in which each molecule has a different number of attacking points), the apparent $\mathrm{Km}$ and Vmax values of Man 58 on mannan were measured. When Man 58 was restricted to mannan as the substrate, the rate dependence of the $\beta$-mannanase reaction followed Michaelis-Menten kinetics. Non-linear regression data analysis showed an apparent $K_{\mathrm{m}}$ value of $3.29 \mathrm{mg} / \mathrm{mL}$ and $V_{\max }$ value of $1.76 \mathrm{IU} / \mathrm{mL}$. Man 58 exhibited a lower apparent $K_{\mathrm{m}}$ value than the $\beta$-mannanases from Pantoea agglomerans A021 (P. agglomerans A021) and Mytilus edulis (M. edulis) [26,27]. The effects of metal ions and EDTA on Man 58 activity were also investigated (Table 1). Man 58 was inhibited by $\mathrm{MgSO}_{4}, \mathrm{FeCl}_{3}, \mathrm{CuSO}_{4}, \mathrm{MgCl}_{2}, \mathrm{ZnCl}_{2}, \mathrm{ZnSO}_{4}, \mathrm{CuCl}_{2}, \mathrm{KCl}$ and EDTA and activated by $\mathrm{FeSO}_{4}$ and $\mathrm{CoCl}_{2}$ at $10 \mathrm{mM}$ concentration. Unlike the activity of Man26P from P. agglomerans A021, Man 58 activity was not enhanced in the presence of $\mathrm{NaCl}$ [26]. Tamaru et al. [28] also reported an inhibitory effect of EDTA on $\beta$-mannanase produced by Vibrio sp. strain MA-138.

The inhibitory effect of phenols on Man 58 was evaluated by incubating the enzyme with phenolic compounds and then measuring its residual mannanase activity (Table 2). Cinnamic acid was the only phenolic compound with a low inhibitory effect (7\%) on Man 58. On the contrary, ferulic acid caused a 51\% increase in enzymatic hydrolysis of mannan. Moreira et al. [29] investigated the inhibitory or deactivating effects of phenolic compounds on two purified xylanases (Xyl T1 and Xyl T2) from A. terreus. Xyl T1 was inhibited to a greater or lesser degree by phenolic compounds, while Xyl T2 was highly resistant to the inhibitory effects of all phenolic compounds tested. Although the inhibitory effects of phenolic compounds on cellulases and hemicellulases have been documented in the literature, little is known about the nature of these interactions and their inhibitory mechanisms [30,31]. Further studies are necessary for a better understanding of the mechanisms involved in this enzymes resistance to phenolic compounds. On the other hand, the incubation of Man 58 with autohydrolysis liquor [22], 
produced at $200{ }^{\circ} \mathrm{C}$ after 50 min of pretreatment, resulted in a significant loss of activity. Although the liquor obtained after autohydrolysis is rich in xylo-oligosaccharides that act as inducers and can be used as substrate for xylan-degrading enzymes production, under these conditions, the activity of Man 58 was inhibited by $64 \%$. However, incubation of Man 58 with the same liquor obtained after 30 min of pretreatment showed a lower inhibitory effect (25\%).

Table 1. The effect of metal ions and ethylenediaminetetraacetic acid (EDTA) in activity of Man 58.

\begin{tabular}{ccc}
\hline \multicolumn{3}{c}{ Man 58 } \\
\hline $\begin{array}{c}\text { Metal Ions and } \\
\text { EDTA }\end{array}$ & $\mathbf{1 ~ m M}$ & $\mathbf{1 0} \mathbf{~ m M}$ \\
\hline Control & $100.00 \pm 0.057$ & $100.00 \pm 0.075$ \\
$\mathrm{MgSO}_{4}$ & $80.24 \pm 0.039$ & $91.90 \pm 0.017$ \\
$\mathrm{FeSO}_{4}$ & $105.66 \pm 0.034$ & $121.99 \pm 0.046$ \\
$\mathrm{CoCl}_{2}$ & $92.68 \pm 0.086$ & $110.86 \pm 0.022$ \\
$\mathrm{FeCl}_{3}$ & $79.21 \pm 0.036$ & $62.42 \pm 0.030$ \\
$\mathrm{CuSO}_{4}$ & $81.50 \pm 0.098$ & $65.00 \pm 0.028$ \\
$\mathrm{CaCl}_{2}$ & $101.50 \pm 0.024$ & $87.53 \pm 0.023$ \\
$\mathrm{MgCl}_{2}$ & $86.06 \pm 0.029$ & $84.50 \pm 0.035$ \\
$\mathrm{ZnCl}_{2}$ & $95.90 \pm 0.030$ & $87.25 \pm 0.057$ \\
$\mathrm{ZnSO}_{4}$ & $94.09 \pm 0.043$ & $89.76 \pm 0.047$ \\
$\mathrm{CuCl}_{2}$ & $90.39 \pm 0.089$ & $64.29 \pm 0.068$ \\
$\mathrm{KCl}_{\mathrm{NaCl}}$ & $81.65 \pm 0.133$ & $94.12 \pm 0.047$ \\
$\mathrm{EDTA}$ & $106.93 \pm 0.077$ & $92.52 \pm 0.010$ \\
& $73.30 \pm 0.028$ & $89.05 \pm 0.023$ \\
\hline
\end{tabular}

Table 2. The effect of phenolic compounds in activity of Man 58.

\begin{tabular}{cc}
\hline \multicolumn{2}{c}{ Man 58 } \\
\hline \multicolumn{2}{c}{ Relative Activity (\%) } \\
\hline Control & $100.00 \pm 0.024$ \\
Ferulic acid & $151.06 \pm 0.008$ \\
Cinnamic acid & $93.37 \pm 0.010$ \\
P-coumaric acid & $103.24 \pm 0.006$ \\
4-hydroxybenzoic acid & $107.89 \pm 0.026$ \\
Tannic acid & $98.16 \pm 0.014$ \\
Vanillin & $98.02 \pm 0.038$ \\
\hline
\end{tabular}

\section{Conclusions}

In conclusion, the partially purified $\beta$-mannanase (Man 58) from A. foetidus was thermostable and showed a great resistance to phenolic compounds. It is noteworthy that the majority of $\beta$-mannanase activity persisted after treatment over a wide range of $\mathrm{pH}$ and high temperature conditions. All of these properties indicate that Man 58 is an attractive enzyme for potential future industrial applications, especially in the paper, feed and food industries. 


\section{Acknowledgments}

E.X.F.F. and J.C.I.M. are recipients of a research fellowship from the Brazilian Research Council (CNPq). This work was funded by CNPq (research grants 470265/2011-6, 563260/2010-6 and 563823/2010-0), the Foundation for Research Support of Federal District (research grants 193000584/2009, 193.000.470/2011 and 193.000.043/2012) and the National Institute of Science and Technology of Bioethanol.

\section{Author Contributions}

E.X.F.F. and J.C.I.M conceived, designed, performed and analyzed the experiments of production, purification and characterization of $\beta$-mannanase; G.P.S.N and C.F.S.C conceived, designed, performed and analyzed the experiments of bromatological analysis; M.L.T.M.P. and M.M. conceived, designed, performed and analyzed the experiments of effect of autohydrolysis Liquor.

\section{Conflicts of Interest}

The authors declare no conflict of interest.

\section{References}

1. Akinyele, J.B.; Olaniyi, O.O.; Adetunji, C.O. Screening and optimization of nutritional conditions for mannanase production by Penicillium italicum LAD-A5 in solid state cultivation. J. Biotechnol. Pharm. Res. 2013, 4, 103-109.

2. Ferreira, H.M.; Filho, E.X.F. Purification and characterization of a $\beta$-mannanase from Trichoderma harzianum strain T4. Carbohydr. Polym. 2004, 57, 23-29.

3. Moreira, L.R.S.; Filho, E.X.F. An overview of mannan structure and mannan-degrading enzyme systems. Appl. Microbiol. Biotechnol. 2008, 79, 165-178.

4. Malgas, S.; van Dyk, J.S.; Pletschke, B.I. A review of the enzymatic hydrolysis of mannans and synergistic interactions between $\beta$-mannanase, $\beta$-mannosidase and $\alpha$-galactosidase. World $J$. Microbiol. Biotechnol. 2015, 31, 1167-1175.

5. Puls, J.; Schuseil, J. Chemistry of hemicelluloses: Relationship between hemicellulose structure and enzymes required for hydrolysis. In Hemicellulose and Hemicellulases; Coughlan, M.P., Hazlewood, G.P., Eds.; Portland Press: London, UK, 1993; pp. 1-27.

6. Singh, S.; Madlala, A.M.; Prior, B.A. Thermomyces lanuginosus: Properties of strains and their hemicellulases. FEMS Microbiol. Rev. 2003, 27, 3-16.

7. Malgas, S.; van Dyk, J.S.; Pletschke, B.I. $\beta$-Mannanase (Man26A) and $\alpha$-galactosidase (Aga27A) synergism - A key factor for the hydrolysis of galactomannan substrates. Enzym. Microb. Technol. 2015, 70, 1-8.

8. Yang, H.; Shi, P.; Lu, H.; Wang, H.; Luo, H.; Huang, H.; Yang, P.; Yao, B. A thermophilic $\beta$-mannanase from Neosartorya fischeri $\mathrm{P} 1$ with broad $\mathrm{pH}$ stability and significant hydrolysis ability of various mannan polymers. Food Chem. 2015, 173, 283-289. 
9. Adiguzel, A.; Nadaroglu, H.; Adiguzel, G. Purification and characterization of $\beta$-mannanase from Bacillus pumilus (M27) and its applications in some fruit juices. J. Food Sci. Technol. 2015, 52, 5292-5298.

10. Zhang, H.; Sang, Q. Production and extraction optimization of xylanase and $\beta$-mannanase by Penicillium chrysogenum QML-2 and primary application in saccharification of corn cob. Biochem. Eng. J. 2015, 97, 101-110.

11. Chiyanzu, I.; Brienzo, M.; García-Aparicio, M.P.; Görgens, J.F. Application of Endo- $\beta-1,4, D-m a n n a n a s e$ and cellulase for the release of mannooligosaccharides from steam-pretreated spent coffee ground. Appl. Biochem. Biotechnol. 2014, 172, 3538-3557.

12. Lee, J.T.; Bailey, C.A.; Cartwright, A.L. $\beta$-Mannanase ameliorates viscosity-associated depression of growth in broiler chickens fed guar germ and hull fractions. Poult. Sci. 2003, 82, 1925-1931.

13. Siqueira, F.G.; Filho, E.X.F. Plant Cell Wall as a substrate for the production of enzymes with industrial applications. Mini-Rev. Org. Chem. 2010, 7, 54-60.

14. Turner, P.; Mamo, G.; Karlsson, E.N. Potential and utilization of thermophiles and thermostable enzymes in biorefining. Microb. Cell Fact. 2007, 6, 1-23.

15. Lin, L.; Yan, R.; Liu, Y.; Jiang, W. In-depth investigation of enzymatic hydrolysis of biomass wastes based on three major components: Cellulose, hemicellulose and lignin. Bioresour. Technol. 2010, 101, 8217-8223.

16. Miller, G.L. Use of Dinitrosalicylic Acid Reagent for Determination of Reducing Sugars. Anal. Chem. 1959, 31, 426-428.

17. Bradford, M.M. A rapid and sensitive method for the quantitation of microgram quantities of protein utilizing the principle of protein-dye binding. Anal. Biochem. 1976, 72, 248-254.

18. Laemmli, U.K. Cleavage of structural proteins during the assembly of the head of bacteriophage T4. Nature 1970, 227, 680-685.

19. Blum, H.; Beier, H.; Gross, H.J. Improved silver staining of plant-proteins, RNA and DNA in polyacrylamide gels. Electrophoresis 1987, 8, 93-99.

20. Sunna, A.; Puls, J.; Antranikian, G. Characterization of the xylanolytic enzyme system of the extreme thermophilic anaerobic bacteria Thermotoga maritima, T-neapolitana, and T-thermarum. Comp. Biochem. Physiol. 1997, 118, 453-461.

21. Leatherbarrow, R.J. Enzfitter Manual, a Non-Linear Curve Fitting Program for Windows; Biosoft: London, UK, 1999; 1-104.

22. Michelin, M.; Polizeli, M.L.T.M.; Ruzene, D.S.; Silva, D.P.; Ruiz, H.A.; Vicente, A.A.; Jorge, J.A.; Terenzi, H.F.; Teixeira, J.A. Production of xylanase and b-xylosidase from autohydrolysis liquor of corncob using two fungal strains. Bioprocess Biosyst. Eng. 2012, 35, 1185-1192.

23. Naganagouda, K.; Salimath, P; Mulimani, V.H. Purification and Characterization of Endo- $\beta-1,4$ Mannanase from Aspergillus niger $g r$ for Application in Food Processing Industry. J. Microbiol. Biotechnol. 2009, 19, 1184-1190.

24. Benech, R.O.; Li, X.; Patton, D.; Powlowski, J.; Storms, R.; Bourbonnais, R.; Paice, M.; Tsang, A. Recombinant expression, characterization, and pulp prebleaching property of a 
Phanerochaete chrysosporium endo-3-1,4-mannanase. Enzym. Microb. Technol. 2007, 41, 740-747.

25. Kote, N.V.; Patil, A.G.G.; Mulimani, V.H. Optimization of the Production of Thermostable endo- $\beta-1,4$ Mannanases from a Newly Isolated Aspergillus niger $g r$ and Aspergillus flavus gr. Appl. Biochem. Biotechnol. 2009, 152, 213-223.

26. Wang, J.; Shao, Z.; Hong, Y.; Li, C.; Fu, X.; Liu, Z. A novel $\beta$-mannanase from Pantoea agglomerans A021: Gene cloning, expression, purification and characterization. World J. Microbiol. Biotechnol. 2010, 26, 1777-1784.

27. Xu, B.; Sellos, D.; Janson, J.C. Cloning and expression in Pichia pastoris of a blue mussel (Mytilus edulis) $\beta$-mannanase gene. Eur. J. Biochem. 2002, 269, 1753-1760.

28. Tamaru, Y.; Araki, T.; Amagoi, H.; Mori, H.; Morishita, T. Purification and characterization of an extracellular $\beta$-1,4-mannanase from a marine bacterium, Vibrio sp. strain MA-138. Appl. Environ. Microbiol. 1995, 61, 4454-4458.

29. Moreira, L.R.S.; Campos, M.C.; Siqueira, P.H.V.M.; Silva, L.P.; Ricart, C.A.O.; Martins, P.A.; Queiroz, R.M.L.; Filho, E.X.F. Two $\beta$-xylanases from Aspergillus terreus: Characterization and influence of phenolic compounds on xylanase activity. Fungal Gen. Biol. 2013, 60, 46-52.

30. Boukari, I.; O'donohue, M.; Rémond, C.; Chabbert, B. Probing a family GH11 endo- $\beta$-1,4-xylanase inhibition mechanism by phenolic compounds: Role of functional phenolic groups. J. Mol. Catal. B 2011, 72, 130-138.

31. Kim, Y.; Ximenes, E.A.; Monsier, N.S.; Ladisch, M.R. Soluble inhibitors/deactivators of cellulase enzymes from lignocellulosic biomass. Enzym. Microb. Technol. 2011, 48, 408-415.

(C) 2015 by the authors; licensee MDPI, Basel, Switzerland. This article is an open access article distributed under the terms and conditions of the Creative Commons Attribution license (http://creativecommons.org/licenses/by/4.0/). 